\title{
O TEATRO DAS RELAÇÕES N' AS ORIGENS DO PENSAMENTO GREGO DE VERNANT
}

\author{
Tiago Rickli ${ }^{1}$ \\ Universidade Federal do Paraná (UFPR) \\ https://orcid.org/0000-0001-7001-5302
}

\begin{abstract}
RESUMO:
Neste estudo, dedicado especificamente ao livro As Origens do Pensamento Grego, gostaríamos de mostrar como o método de análise de Vernant dos diferentes momentos que definiram a história humana procede, sobretudo, através do exame sistemático das relações constituintes que os diferenciaram como tal ou qual. Todavia, à medida que explicitado em seu desenvolvimento, acreditamos também poder demonstrar a existência de um pensamento implicando uma série conceitos que, do ponto de vista de uma reflexão filosófica, trazem inseparavelmente consigo uma compreensão sobre o problema da natureza da ação, assim como da relação entre uma ação e o sentido ou animação que ela exprime no seu exercício. Definindo os diferentes elementos e papéis de um contexto histórico, não isoladamente à maneira de termos em si e por si, mas a partir do complexo jogo de interações em que eles se encontram, Vernant demonstra conceber um personagem como aquilo que se caracteriza pelas ações que exerce, mas estas ações, por sua vez, como uma atividade que não se diferencia como tal senão juntamente àquilo com o qual ela interage. Ademais, tal condição mostrou-se para nós como acompanhada pela capacidade da ação de exprimir as relações constituintes que ela entretém com seu entorno. Longe de sugerir uma Forma atemporal que subsistiria indiferente às mudanças acontecendo ao nível das interações entre os elementos de uma rede de relações, as animações expressas pelos seus personagens são autóctones e variam na mesma velocidade que sua atividade se transforma.
\end{abstract}

PALAVRAS-CHAVE: Relação; Diferenciação recíproca; Ação; Expressão; Sentido.

\section{THE THEATER OF RELATIONS IN VERNANT'S THE ORIGINS OF GREEK THOUGHT}

\section{ABSTRACT:}

In this study, dedicated specifically to The Origins of Greek Thought, we would like to show how Vernant's analysis method of the different moments that defined the human's history proceeds above all through the systematic examination of the constitutive relations that differentiated them as such or such. However, as its development is unfolded, we also believe that we can demonstrate the existence of a thought implicating a series of concepts that, from the perspective of a philosophical reflection, have inseparably bounded to them an understanding on the problem of the nature of action, as well as the relation between action and the sense or animation that it expresses in its performance. When defining the different elements and roles of a historical context, not as isolated terms in and by themselves, but through the complex state of interactions which they found themselves in, Vernant demonstrates to conceive a character as that which distinguishes itself for the actions he performs, but these actions, on the other hand, as an activity that solely differentiates as such or such together with what it's interacting with. Furthermore, this condition has shown us to be accompanied by the capacity of action to express the constitutive relations that it entertains with its surroundings. Far from suggesting a timeless Form that could subsist indifferent to the changes happening at the level of the interactions between the elements of a network of relations, the animations expressed by its characters are autochtonous and varies at the same speed in which their activity transforms.

KEYWORDS: Relation; Reciprocal Differentiation; Action; Expression; Sense.

1 Doutorando em Filosofia na Universidade Federal do Paraná (UFPR), Paraná - Brasil. E-mail: tiago.rickli@gmail.com.

RICKLI, Tiago. O teatro das relações n’As origens do pensamento grego de Vernant. Griot : Revista de Filosofia, Amargosa/Bahia, v.17, n.1, p.269-282, junho/2018. 


\title{
Da interação como relação de diferenciação e de sua expressividade autóctone
}

\begin{abstract}
No teatro da repetição, experimenta-se forças puras, traçados dinâmicos no espaço que agem sem intermediários sobre o espírito e que o unem diretamente à natureza e à história, uma linguagem que fala antes das palavras, gestos que se elaboram antes dos corpos organizados, máscaras antes dos rostos, espectros e fantasmas antes dos personagens (DELEUZE, 1968, p. 19, tradução nossa)
\end{abstract}

É notável a função investigativa que as relações constituintes de uma organização social preenchem nos estudos de Vernant. Com efeito, seja o anax micênico ou a escrita na polis, é através da descrição das relações estendidas ao redor do objeto investigado, isto é, entretidas juntamente àquilo lhe é coexistente, que seu modo de ser próprio se revela em seus detalhes. Por exemplo, à rede de relações cujos membros desempenham funções específicas delegadas por um termo central eminentemente responsável pela ordenação e regulação de seu conjunto ${ }^{2}$, Vernant dá o nome de sistema palaciano micênico. Tal termo central, por sua vez, é ele próprio um membro ou personagem dessa rede: desempenhando o poderoso papel de decidir como devem ser executados os ritos religiosos ${ }^{3}$, os movimentos das unidades militares ${ }^{4}$, e a circulação de produtos e serviços da economia micênica ${ }^{5}$, é o soberano anax quem ocupa o foco do qual a ordenação do mundo micênico deve irradiar. Como observado pelo historiador, não há lugar num tal meio para a prática de um comércio que se autorregule espontânea e autonomamente, pois, longe de decidir o destino de seu trabalho e de seus produtos independentemente dos interesses do Palácio, os agentes da economia micênica, ao contrário, agem de modo a pôr em movimento uma ordenação determinada por outrem, ou seja, pela sua relação de observância às determinações do anax. Controlando-os em sua interatividade uns com os outros, interferindo no entre das ações e reações trocadas e trocáveis pelos agentes de circulação de produtos e serviços, o Palácio atua de modo a prescrever e fiscalizar a prática de relações econômicas de seu interesse. Poder-se-ia dizer que o papel de regulador econômico é inseparável como tal de sua relação com essa função de produção tanto quanto, inversamente, essa atividade de circulação de produtos e serviços é inseparável da atividade de controle preenchida acima de tudo pelo

\footnotetext{
2 “A vida social aparece centrada em torno do palácio cujo papel é ao mesmo tempo religioso, político, militar, administrativo, econômico. Nesse sistema econômico denominado palaciano, o rei concentra e unifica em sua pessoa todos os elementos do poder, todos os aspectos da soberania" Vernant, 1962, p. 30 , tradução nossa.

3 "O anax é o responsável pela vida religiosa: ele ordena com precisão o seu calendário, vela pela observância do ritual, pela celebração das festas em honra aos diversos deuses, estabelece os sacrifícios, as oblações vegetais, a taxa das oferendas exigidas de cada um de acordo com a sua classe" Vernant, 1962, p. 35-36, tradução nossa.

4 “No cume da organização social o rei carrega o título de wa-na-ka, anax. Sua autoridade parece se exercer em todos os níveis da vida militar: é o palácio que regula os pedidos de armas, o equipamento dos carros, o recrutamento, o enquadramento, a composição, a movimentação das unidades" Vernant, 1962, p. 35, tradução nossa.

5 "Parece que a administração real regulamentava a distribuição, a troca e a produção dos bens. Pelo intermédio do Palácio que determina, do centro da rede, o duplo circuito das prestações e gratificações, os produtos, os trabalhos, os serviços, igualmente codificados e contabilizados, circulam e são trocados uns com os outros" Vernant, 1962, p. 31, tradução nossa.
}

RICKLI, Tiago. O teatro das relações n’As origens do pensamento grego de Vernant. Griot : Revista de Filosofia, Amargosa/Bahia, 
Soberano, mas também delegada a alguns de seus subordinados. Recíprocas, uma atividade não se diferencia como tal ou qual senão na sua relação com a outra.

Ao concorrer no exercício de uma relação determinada, os seus agentes passam a desempenhar modos de ser diferentes, mas recíprocos: controlar as trocas de produtos e serviços $e$ trocar produtos e serviços de acordo com um controle, regular o fornecimento da matéria-prima necessária para produzir $e$ atender às demandas de produção do Palácio ${ }^{6}$ : "controlar-trocar", "regular-produzir". Logo, apesar de ocupar o cume da hierarquia micênica, o papel efetivamente preenchido pelo anax não se basta ou subsiste em si e por si, independentemente do conjunto das interações materiais que ele entretém com aquilo que lhe é coexistente: com efeito, modifique-se os agentes em suas relações e ter-se-á, correspondentemente, a diferenciação dos modos de ser que eles exercem em reciprocidade. Ademais, assim como é próprio do agente ser a atividade que ele exerce, mas não se diferenciar em sua atividade senão juntamente àquilo com o qual ele se reciproca deste ou daquele modo, também é próprio ao sentido que os seus movimentos exprimem uma condição radicalmente relacional. Por exemplo, quando Vernant procura explicitar o valor semântico $d a$ relação "adquirir-ceder" entre os micênicos, ele não se apressa em separar seus termos e isolá-los um do outro; ao contrário, apreendendo-os em sua recíproca diferença, Vernant tanto explica a relação "adquirir-ceder" em seu sentido particular, como também a distingue de outras relações com as quais ela poderia facilmente ser confundida, a saber, as relações "comprar-vender" e de escambo em geral:

\footnotetext{
Não se vê haver lugar para um comércio privado numa economia deste gênero. Se existem termos que significam adquirir e ceder, não se encontra testemunho de uma forma de pagamento em ouro ou prata, nem de uma equivalência estabelecida entre mercadorias e metais preciosos. Parece que a administração real regulamentava a distribuição, a troca e a produção dos bens. (Vernant, 1962, p. 30-31, tradução nossa)
}

Aquele que adquire não procura trocar alguma outra coisa com aquele que cede. Com efeito, as relações econômicas entre os micênicos não se davam à maneira de um "comprar-vender", pois não há a troca mútua do objeto cedido-adquirido por uma quantidade equivalente em prata ou ouro. Ela tampouco se exprime como alguma espécie de escambo, pois aquele que cede não recebe necessariamente daquele que adquire alguma outra coisa em troca. Essa relação historicamente sem nome de trocas controladas, que Vernant hesita em reconhecer como algum tipo de comércio privado e que é constituinte da rede de relações que as ações e reações dos micênicos colocam em movimento, exprime ou assinala uma mesma diferença cujos termos, apesar de desiguais, são inseparáveis em seu sentido um do outro: "adquirir-ceder". Os termos expressos numa relação constituinte são como os espelhos paralelos: o sentido de um tanto reflete o de seu correlato quanto está refletido no dele. Irredutível à identidade de uma Essência consigo mesma, é da natureza do sentido de uma relação a mútua continuidade de seus termos desiguais um no outro, ou seja, ser uma diferença ou aquilo que difere de si mesmo.

\footnotetext{
6 “Os escribas contabilizam em seus arquivos o que concerne: [...] aos diversos ofícios especializados, com os recursos a fornecer em matéria-prima e as ordens de produtos concluídos; à mão-de-obra, disponível ou ocupada" Vernant, 1962, pg. 30, tradução nossa.
}

RICKLI, Tiago. O teatro das relações n'As origens do pensamento grego de Vernant. Griot : Revista de Filosofia, Amargosa/Bahia, v.17, n.1, p.269-282, junho/2018. 
Um agente é dito agir de tal ou tal modo em razão da animação que exprime nos movimentos que troca com aquilo que lhe é coexistente. Ao interativamente se conduzir de modo a controlar a produtividade gerada pelos micênicos, o anax se organiza em seus gestos num modo de coexistir juntamente àquilo com que ele interage, mas também se exprime como um dos lados de uma mesma relação cujo entretenimento o diferencia como tal. Com efeito, caso os agentes que preenchem sua capacidade de agir com a geração e troca controladas de produtos e serviços renunciassem a essa atividade, não apenas esses personagens micênicos imediatamente se desdiferenciariam em seu modo de ser, mas igualmente a atividade de controle e regulação da produtividade micênica se veria, evidentemente, interrompida, inoperacional, ineficaz, inexpressa. Entretanto, apesar de atuar do centro desta rede de relações que é o sistema palaciano micênico, a economia palaciana não é unicamente administrada pelo anax, e este tampouco exerce o papel de soberano de modo restrito à atividade econômica:

\begin{abstract}
Nesse sistema de economia chamado de palaciano, o rei concentra e unifica em sua pessoa todos os aspectos do poder, todos os aspectos da soberania. Pelo intermédio de escribas que formam uma classe profissional estabelecida na tradição, graças a uma complexa hierarquia de dignitários do palácio e de inspetores reais, ele controla e regulamenta minuciosamente todos os setores da vida econômica, todos os domínios da atividade social (Vernant, 1962, pg. 30, tradução nossa)
\end{abstract}

Entre o soberano e o micênico comum, há feixes de relações de diversas ordens, correspondendo aos diferentes aspectos de sua soberania: militar, religioso, político, econômico, administrativo. Contudo, as interações que as estendem de um polo ao outro não se efetuam de maneira imediata, mas através de uma cadeia de elos ou personagens intermediários que asseguram, pelas suas respectivas posições e papéis, o prolongamento e a eficácia das ordens do soberano por toda a extensão da sociedade micênica. Esses agentes - alguns descritos como encarregados de rigorosamente fiscalizar, registrar e arquivar o conjunto das atividades constituintes da vida micênica ${ }^{7}$, outros de chefiar unidades militares ou de manter a corte palaciana ligada aos comandos locais das aldeias e domínios rurais sob o controle do anax ${ }^{8}$ - não se deixam diferenciar, como bem o observou Vernant, pela relação característica de

\footnotetext{
7 "Os escribas contabilizam em seus arquivos o que concerne: ao gado e à agricultura, à tenência das terras, avaliadas em medidas de cereais (sejam as taxas de arrendamento ou as rações de sementes); aos diversos ofícios especializados, com os recursos a fornecer em matéria-prima e as ordens de produtos concluídos; à mão-de-obra, disponível ou ocupada; aos escravos, homens, mulheres e crianças, tanto particulares como do rei; às contribuições de toda espécie impostas pelo Palácio aos indivíduos e às coletividades, aos bens já entregues e aqueles ainda a serem recebidos; ao recrutamento de homens a serem fornecidos por certas aldeias para equipar os navios reais com remadores; à composição, ao comando, à movimentação das unidades militares; aos sacrifícios aos deuses, às taxas previstas para as oferendas, etc." Vernant, 1962, p. 30, tradução nossa.

8 "Ao lado do wa-na-ka, o la-wa-ge-tas, segundo personagem do reino, representa o chefe do laos, literalmente o povo armado, o grupo dos guerreiros. Trajando como uniforme um modelo especial de

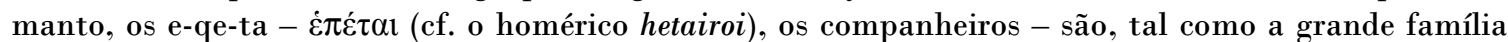
hitita, dignitários do palácio que formam o séquito do rei ao mesmo tempo que chefes colocados à frente de uma ohka, uma unidade militar, ou oficiais que asseguram a ligação da corte com os comandos locais" Vernant, 1962, p. 37, tradução nossa.
}

RICKLI, Tiago. O teatro das relações n’As origens do pensamento grego de Vernant. Griot : Revista de Filosofia, Amargosa/Bahia, 
um funcionário público com o Estado, pois, no palacianismo micênico, somente o soberano detém em absoluto todo o poder de comandar, decidir e ordenar e, deste modo, é somente através de sua atribuição pessoal que qualquer autoridade pode ser reconhecida a algum outro indivíduo que não seja ele próprio o soberano ${ }^{9}$. Ademais, esse vínculo pessoal, firmado mutuamente na delegação confiada pelo monarca $e$ no seu cumprimento pelo subordinado, não resulta na transferência ao último de qualquer liberdade ou autonomia, e tão menos tem tal interação por efeito repartir a autoridade concentrada no primeiro de modo a distribuí-la: no "delegar-executar" micênico, o soberano retém consigo a autoridade exclusiva e permanente sobre a ação ou função que ele permite que seja executada por outrem, enquanto que o seu subordinado executa apenas a título de concessão essa função privilegiada cujo direito à ação não lhe pertence. $\mathrm{Na}$ rede de relações do palacianismo micênico, deter ou possuir um poder absoluto, portanto, consiste em reservar única e exclusivamente a um agente funções ditas soberanas $e$ apenas autorizar que outros as executem de maneira "lacunar", isto é, sem possuí-las como um direito próprio. Reter a autoridade ao delegar $e$ exercer sem direito à posse são, assim, os atos correlatos da relação pela qual rei e dignitário, ao mesmo tempo, tanto se diferenciam reciprocamente quanto se ligam um ao outro no palacianismo micênico. Rei e dignitário são ambos modos de ser, mas modos de ser que existem e se exprimem relacionalmente.

"Rei-dignitário", "soberano-micênico comum", "fiscal-artesão/camponês", são papéis expressos na atualização de uma rede de relações constituintes cujos agentes, ao mesmo tempo que se diferenciam reciprocamente nas ações e reações que trocam entre si, igualmente se distribuem, uns em relação aos outros, num modo de organização determinado, qual seja: nesse sistema em que um polo de controle central prolonga uma atividade regulatória através de elos intermediários até os demais polos "satélites". Do ponto de vista relacional, não existem interações cujas ações subsistam em si mesmas, isto é, indiferentes umas às outras, nem tampouco sentidos cujos termos desiguais sejam independentes uns dos outros, de modo que aquele que age e se exprime, sempre age e se exprime juntamente àquilo que lhe é coexistente. Ora, é orientando-se pela distinção entre relações de diferenciação recíproca que Vernant demonstra que o basileus micênico, diferentemente do modo de existência que o seu homônimo homérico sugere, qual seja, o de um rei em seu palácio, se diferencia, ao contrário, por desempenhar um papel relativo a uma situação inteiramente diversa: entre os micênicos, é chamado basileus o responsável por fiscalizar ou administrar a metalurgia de um domínio rural ou aldeia satélite sob o consentimento do anax ${ }^{10}$. Vê-se,

\footnotetext{
9 “Em todos os níveis da administração palaciana, é um vínculo pessoal de fidelidade que, com efeito, une ao rei os diversos dignitários do Palácio: eles não são funcionários a serviço do Estado, mas servos do rei encarregados de manifestar, em todo lugar que a sua confiança os colocou, este poder absoluto de comando que se encarna no monarca. No quadro da economia palaciana, ao lado de uma divisão em geral muito elevada das tarefas, de uma especialização funcional com uma cascata de fiscais e chefes de fiscalização, também se constata uma variação nas atribuições administrativas que se sobrepõem, cada representante por delegação do rei exercendo, ao seu nível, uma autoridade que cobre sem limites, em princípio, todo o campo da vida social" Vernant, 1962, p. 33, tradução nossa.

10 “É nesse quadro provincial que aparece, contra toda expectativa, o personagem que porta o título que nós normalmente teríamos traduzido por rei, o pa-si-re-u, o basileus homérico. Ele não é o Rei em seu palácio, mas, precisamente, um simples senhor, mestre de um domínio rural e vassalo do anax. Num sistema econômico em que tudo é contabilizado, esse vínculo de vassalidade reveste sobretudo a forma de uma responsabilidade administrativa: vemos o basileus fiscalizar a distribuição dos recursos
}

RICKLI, Tiago. O teatro das relações n’As origens do pensamento grego de Vernant. Griot : Revista de Filosofia, Amargosa/Bahia, v.17, n.1, p.269-282, junho/2018. 
pois, que a noção de basileus se confunde com a animação que a sua atividade exprime, mas sua animação, por sua vez, encontra-se compreendida num sentido cujos termos desiguais continuam-se um no outro, inseparáveis em sua diferença: "administrar um domínio-atribuir uma função", "fiscalizar a produção local-produzir a serviço do Palácio". E de que modo se diferencia o camponês ou o "homem do damos" dos demais personagens desse teatro de relações que é o sistema palaciano micênico? Ora, por exercer agricultura numa terra comum ou coletiva ${ }^{11}$, por lutar na guerra como um peão, e por permanecer em silêncio diante das decisões do Conselho dos Anciãos: uma relação com aqueles que se compartilha uma terra, com aqueles que se combate, e com a assembleia da aldeia à qual se pertence ${ }^{12}$.

Excluído da participação nas decisões que concernem à sua aldeia, o limite ao qual o camponês ou homem do damos pode se levar em sua capacidade de agir e reagir sem comprometer o liame que ele entretém com o Conselho está na vizinhança de um "escutar em silêncio àqueles que estão qualificados para falar", e de um "não demonstrar mais do que um ruído de aprovação ou descontentamento". Com efeito, ter poder decisório numa assembleia é, por exemplo, uma atividade que a capacidade de agir dos homens do damos não poderia passar a incorporar sem, concomitantemente, também modificar aquela dos Anciões e de seu Conselho, qual seja, a de exclusivamente deter na aldeia a autoridade para falar. Diferenciadas na mesma velocidade que as ações e reações que as exprimem, as animações ou sentidos não informam uma Essência una e imutável, indiferente aos agentes que devêm com o exercício de sua própria capacidade de agir. Autóctones e contemporâneas à ação, as animações expressas mudam juntamente com as mudanças dos gestos que as exprimem, de modo que o homem do damos não poderia se modificar em sua capacidade de agir sem se desdiferenciar em seu modo de ser e, consequentemente, perder o nome segundo o qual a história o definiu, isto é, sem passar a exprimir uma noção diversa àquela pela qual ele se fez previamente discernir: "linguagem que fala antes das palavras, gestos que se elaboram antes dos corpos organizados, máscaras antes dos rostos, espectros e fantasmas antes dos personagens" (Deleuze, 1968, p. 19, tradução nossa).

\section{Da contemporaneidade da expressão ao devir da interação}

Um agente não subsiste indiferente às variações das relações em que se investe, mas se diferencia e desdiferencia nelas, de modo que modificar-se em sua capacidade de agir e reagir é variar-se as relações constituintes que se entretém ou, inversamente,

em bronze destinados aos ferreiros que, em seu território, trabalham para o Palácio" Vernant, 1962, pg. 39 , tradução nossa.

11 “As ki-ti-me-na ko-to-na são terras privadas, apropriadas, contrariamente às ke-ke-me-na ko-to-na, vinculadas ao damos, terras comuns dos demos das aldeias, propriedade coletiva do grupo rural, cultivadas segundo o sistema open-field e talvez sendo o objeto de uma redistribuição periódica" Vernant, 1962, p. 38, tradução nossa.

12 “Os simples camponeses, homens do damos no sentido próprio, que fornecem ao exército a tropa de peões e que, para retomar a fórmula homérica, não contam mais no Conselho do que na guerra, formam no melhor dos casos os espectadores que escutam em silêncio àqueles têm qualidade para falar e apenas exprimem os seus sentimentos num rumor de aprovação ou descontentamento" Vernant, 1962, p. 40, tradução nossa.

RICKLI, Tiago. O teatro das relações n'As origens do pensamento grego de Vernant. Griot : Revista de Filosofia, Amargosa/Bahia, 
variar-se as relações diferenciais que se entretém é modificar-se em sua capacidade de agir e reagir. Um agente não simplesmente existe, mas se encontra numa radical condição de coexistência, e é por não se deixar confundir com uma coisa introvertida em si mesma, como se independente fosse das relações que entretém, que toda diferenciação ou desdiferenciação já se faz sempre em reciprocidade. Relacional por natureza, a diferenciação da capacidade de agir é plurilateral, isto é, ela não faz do agente o veículo de uma nova atividade sem torná-lo um dos termos de uma nova relacionabilidade. Eis porque do agente não se pode afirmar que ele tende, tem ou mesmo troca de Forma ou Essência, pois, de fato, ele jamais atualiza ou exprime uma em seus gestos e movimentos: a variação da sua interatividade não passa por Essências, mas apenas por diferenças. Em Sils Maria, filme de Olivier Assayas ${ }^{13}$, a renomada atriz Maria Enders e sua jovem assistente pessoal, Valentine, estudam e ensaiam a peça Maloja Snake na casa de seu falecido autor, Wilhelm Melchior. Ao longo de um comércio de gestos e palavras, Maria e Valentine procuram construir uma interação em que ambas passam a agir e sentir como Helena e Sigrid, a chefe da empresa e sua estagiária em Maloja Snake. Todavia, não é apenas à diferenciação de Maria em Helena e de Valentine em Sigrid que assistimos: Helena não chama Sigrid ao seu escritório para oferecer à estagiária o cargo de assistente sem confessar o seu desejo pela jovem que, em troca, não apenas aceita um cargo, mas também consente em entreter essa relação amorosa desejada por Helena. A atriz renomada $e$ a assistente, a chefe da empresa $e$ a estagiária, a amante $e$ a amada: um rio de relações escorre entre Maria e Valentine, um comércio de movimentos que se repete sem jamais sair ou tampouco chegar a um "É" terminal, simples e uniforme.

Mas o teatro das relações vivido por Maria e Valentine em Sils Maria é também aquele descrito por Vernant em As Origens do pensamento grego. Procedendo através da distinção de relações diferenciais ou de diferenciação recíproca, o historiador ensina à filosofia um conceito de agente que se confunde com o devir de seu modo de agir e reagir, com os papéis ou funções que ele ora encarna, ora abandona, mas essa sua atividade é inseparável como tal ou qual das relações em que ela se atualiza ou se diferencia. Além do mais, Vernant não nos ensina o conceito de um agente assubstancial, radicado numa condição de coexistência, sem com isso também nos mostrar que o sentido dessas relações constituintes, expresso nas interações de algo juntamente àquilo que lhe é coexistente, não remete a qualquer Essência perfeitamente idêntica a si mesma, mas é, justamente, a diferença que ele é. De fato, como não descrever esse intenso comércio plurilateral de movimentos, sem ser levado a discernir os seus sentidos em si mesmos desiguais? Como não falar das interações dos corpos entre si, sem exprimir nessa mesma fala a mútua continuidade de suas animações umas nas outras? É num mesmo movimento que se remete o agente às relações nas quais ele se investe, e que se liberta sua expressividade do modelo de um Inteligível Atemporal, pleno de sua Identidade consigo mesmo.

"Adquirir-ceder", "controlar-trocar", "reter ao delegar-exercer sem posse", "escutar em silêncio-estar qualificado para falar": mais aquém da Inteligência das Essências, há a expressividade da ação. Com as invasões dóricas e o consequente desmanche da rede de relações à qual o sistema palaciano micênico correspondia, os gestos outrora constituintes do anax e dos seus delegados, com seu Palácio Central e

13 ASSAYAS, Sils Maria, 2014.

RICKLI, Tiago. O teatro das relações n'As origens do pensamento grego de Vernant. Griot : Revista de Filosofia, Amargosa/Bahia, v.17, n.1, p.269-282, junho/2018. 
aldeias satélites, deixam de se fazer correntes. Suas animações, antes expressivas, desaparecem, os nomes não encontram mais os agentes que designavam, caem em desuso, no esquecimento, e os poucos preservados têm seu valor semântico alterado: "o rei não apenas mudou de nome, mas de natureza" 14 . Todavia, mais tarde, entre os séculos VIII e VII, os gregos registram em sua história a construção de uma rede de relações bastante diversa daquela antes entretida pelos micênicos, e é se orientando pela sua peculiar distribuição de relações constituintes que Vernant, por sua vez, compara e descreve a natureza desse novo sistema ${ }^{15}$. Escrever, por exemplo, em nada se confunde com a técnica especializada dos escribas micênicos de fiscalizar a circulação de mercadorias, escravos, mão-de-obra e recursos, ou seja, de manter um arquivo privado de registros contábeis. Na polis grega, escreve-se para a leitura de todos: com efeito, a livre difusão das letras entre os gregos em geral capacita-os à prática de sua escrita e leitura, ela ensina tanto a escrever quanto a ler ${ }^{16}$. De saída legível, as inscrições gravadas em monumentos ou guardadas em livros já nascem no doravante domínio público da letra, à vista ou à leitura de todos. Ora, deslocada a dikè da voz privada da basileia para a legibilidade da escrita, a função antes reservada aos basileis de dizer a medida do justo lhes é extraída e incorporada nessa letra comum ao grego em geral, infundida no domínio público e tornada legível, ou seja, exposta sem privilégios à vista de todos, mas não sem tornar a própria letra pública e comum, precisamente, capaz de dizer a medida do justo ${ }^{17}$. Há, no gesto de redação da lei, não

14 “O mundo homérico não conhece mais uma divisão do trabalho comparável àquela do mundo micênico, nem o emprego da mão de obra servil numa escala tão vasta. Ele ignora as múltiplas corporações de "homens de ferramentas" agrupados nas redondezas do palácio ou colocados nas vilas para executar comandos reais. Na queda do império micênico, o sistema palacial é inteiramente devastado; jamais se reerguerá. $O$ termo anax desaparece do vocabulário propriamente político. Para designar a função real, ele é substituído em seu emprego técnico pela palavra basileus, cujo valor estritamente local nós vimos e que, no lugar de uma única pessoa concentrando em si todas as formas de poder, designa, empregada no plural, uma categoria dos Grandes que se situam, todos, no topo da hierarquia social. Abolido o reino do anax, não se encontram mais traço de um controle organizado pelo rei, de um aparelho administrativo, de uma classe de escribas"; "De Micenas a Homero, apaga-se quase que inteiramente o vocabulário dos títulos, dos cargos, das funções civis e militares, da tenência do solo. Destruído o antigo sistema, os poucos termos que subsistem, como basileus ou temenos, não conservam mais exatamente o mesmo valor"; "Com efeito, não basta dizer que no curso desse período a realeza na Grécia se vê despojada de seus privilégios e que, onde ela subsiste, de fato cede lugar a um estado aristocrático; é preciso adicionar que esta basileia já não era mais a realeza micênica. O rei não apenas mudou de nome, mas de natureza" Vernant, 1062, p. 43, p. 46 e p. 47-48 respectivamente, tradução nossa.

15 “O surgimento da polis constitui, na história do pensamento grego, um evento decisivo. [...] desde o seu advento, que se pode situar entre os séculos VIII e VII, ela marca um começo, uma verdadeira invenção; por ela, a vida social e as relações entre os homens tomam uma nova forma, cuja originalidade os Gregos sentirão plenamente a originalidade" Vernant, 1962, p. 56, tradução nossa.

16 "Emprestada dos Fenícios e modificada para uma transcrição mais precisa dos sons gregos, a escrita poderá satisfazer essa função de publicidade porque ela mesma se tornou, quase de maneira equivalente à língua falada, o bem comum de todos os cidadãos. As inscrições mais antigas que nós conhecíamos em alfabeto grego mostram que, desde o século VIII, não se trata de um saber especializado, reservado aos escribas, mas de uma técnica de amplo uso, livremente difundida no público" Vernant, 1962, p. 59, tradução nossa.

17 "Compreende-se assim o alcance de uma reivindicação que surge desde o nascimento da cidade: a redação das leis. Ao escrevê-las, não se faz senão assegurar a sua permanência e fixidez; elas são subtraídas da autoridade privada dos basileis cuja função era "dizer" o direito; elas se tornam bem

RICKLI, Tiago. O teatro das relações n’As origens do pensamento grego de Vernant. Griot : Revista de Filosofia, Amargosa/Bahia, 
apenas a mera transcrição de uma regra falada para o texto, mas a transformação da dikè em letra pública e da letra pública em Lei, e é na mudança da relação do grego com a técnica da escrita/leitura, ou seja, com aquilo que lhe era público e comum, que se efetua um novo modo de ser previamente desconhecido entre os micênicos.

A letra tornada Lei passa a ser capaz de fixar àqueles que ela é comum um código geral de conduta, de instruir aquele que a consulta, de orientar o juízo daquele que julga, de ser revista, debatida, modificada por decreto. Porém, ao incorporarem à letra um papel que a diferencia, é também em sua capacidade de agir e reagir que os gregos se modificam: eles doravante podem submeter essa Lei comum e pública ao debate, à revisão, à modificação por decreto; podem ser instruídos em sua ação por suas diretrizes, orientados em seu juízo pelas suas premissas, cultivados enquanto sociedade segundo o regime que a sua própria legibilidade enuncia. Processo multilateral, na variação da relação em que a letra se torna Lei, o grego devém cidadão da polis. $O$ papel que a letra exprime entre os gregos se faz discernir, portanto, na relação diferencial que a capacidade de agir e reagir dos gregos passa a entreter com essa prática de enunciação. Entre os micênicos, as anotações dos escribas somente armazenavam dados contábeis. Porém, entre os gregos, a legibilidade pública da letra enuncia o direito que outrora coube à voz do basileus dizer.

Ao depositar o escrito Sobre a Natureza no templo de Ártemis, Heráclito deixa disponível para seus potenciais leitores um saber, mas também retira de si a incumbência de apresentá-lo pessoalmente e de responder por ele, reconhece na legibilidade de seus enigmas um poder impessoal de fazer ver e revelar, de despertar naqueles que se tornaram capazes um exercício de pensamento, ou seja, de entreter com o texto uma relacionabilidade determinada ${ }^{18}$. Novos modos de se ler e escrever, portanto, nascem no contexto da polis, mas também de se falar e ouvir. Aquele que discursa sobre os problemas da cidade não encontra mais entre seus concidadãos uma classe de subordinados prontamente dispostos a obedecê-lo, acompanhando a sequência de suas palavras como se escutassem ao encadeamento de comandos ou ordens. À palavra falada não se segue imediatamente uma reação motora no ouvinte. Ao contrário, os que ouvem o fazem à maneira de uma escuta crítica daquilo que a fala enuncia, de suas suposições e consequências mais ou menos imediatas passíveis de serem testadas em sua facticidade, medidas em seus valores. A fala propõe, a escuta avalia.

Ora, mas a escuta não se torna crítica sem a fala se tornar uma prática argumentativa: uma vez convertida em instrumento do exercício político por excelência ${ }^{19}$, a fala passa a exigir do falante um discurso mais elaborado, uma seleção mais criteriosa de suas palavras, um encadeamento de demonstrações ou sequências argumentativas coerentes, convincentes, assim como a forçar no seu ouvinte o

comum, regra geral, suscetível de se aplicar da mesma maneira a todos" Vernant, 1962, p. 60, tradução nossa.

18 “O livro que lhe é atribuído é em geral Sobre a Natureza e se divide em três partes: Do Universo, Política e Teologia. Depositou-o no tempo de Ártemis, como asseveram alguns, e de propósito o escreveu obscuramente, para que só homens capazes pudessem abordá-lo e não fosse facilmente exposto ao desprezado público" Diógenes Laércio, in: Os Pensadores: Os pré-socráticos Vol. I, 1989, p. 47.

19 "Em primeiro lugar, o sistema da polis implica uma extraordinária preeminência da fala sobre todos os outros instrumentos de poder. Ela se torna a ferramenta política por excelência, a chave de toda autoridade no Estado, o meio de comando e domínio de outrem" Vernant, 1962, p. 56, tradução nossa.

RICKLI, Tiago. O teatro das relações n’As origens do pensamento grego de Vernant. Griot : Revista de Filosofia, Amargosa/Bahia, 
exercício de uma escuta afinada a tais procedimentos, dirigida pela necessidade de muito rapidamente avaliar o que quer que o fluxo de palavras do discurso enuncie. Afinal, se na polis o falante discursa de modo a expor, em meio ao público, o seu partido e a oferecê-lo ao debate, à contestação, enfim, ao desafio de seus interlocutores ou adversários, é igualmente preciso que estes consigam reconhecer, quase que simultaneamente à sua enunciação, os seus deslizes e lacunas, as suas consequências indesejadas, para poder então, em troca, ter um meio de confrontá-lo. Ora, ser capaz de elaborar espontaneamente um discurso argumentado, de rapidamente apurar os "não-ditos" implicados numa fala, são atividades que os gregos não contraem ou incorporam à sua capacidade de agir e reagir sem fazer da palavra falada, tão ou mais pública e comum do que a escrita, a instância intermediadora do debate político, o meio comum no qual e pelo qual eles se confrontam e se testam uns aos outros para que as decisões políticas sejam coletivamente determinadas ${ }^{20}$. É na sua relação de diferenciação recíproca com aquilo que lhe era público e comum, ou seja, a palavra escrita e a falada, que o grego tanto se modifica em sua capacidade de agir e reagir, quanto diferencia a letra em Lei e a fala em meio de disputa política.

No entre da interatividade política, os gregos intercalam a fala como veículo de propostas e objeto de avaliações. $O$ falante não mais imediatamente ordena, mas elabora; o ouvinte não mais imediatamente acata, mas reflete. Nenhuma surpresa, pois, que Vernant reconheça no surgimento da polis, isto é, na modificação do exercício da fala em órgão comum de debate político, as origens deste exercício que somente mais tarde será chamado de filosofia ${ }^{21}$. O problema de como proceder diante das necessidades da Cidade passa, então, a ser resolvido em assembleia, coletivamente, pelo e no embate oral, pois o problema de se decidir sobre questões de ordem política não se encontra mais sob a autoridade pessoal deste ou daquele indivíduo, mas foi incorporado nessa fala comum e pública que, convertida tanto em veículo como em meio de decisão política, não passa a carregá-lo consigo sem suspender a possibilidade de sua apropriação particular por algum dos membros da assembleia. Doravante, um discurso apenas será aceito como um encaminhamento resolutivo para questões de ordem política, uma vez que a assembleia que assiste ao confronto das propostas seja persuadida por algum dos lados expostos ${ }^{22}$.

\footnotetext{
20 "Há, deste modo, uma estreita relação entre a política e o logos, um vínculo recíproco. Essencialmente falando, a arte política é manejo da linguagem; e o logos toma consciência de si mesmo, de suas regras, de sua eficácia, de início, através da função política" Vernant, 1962, p. 57, tradução nossa.

21 “Advento da Polis, nascimento da filosofia: os laços entre as duas ordens de fenômenos são demasiado estreitos para que o pensamento racional não apareça, em suas origens, solidário às estruturas sociais e mentais próprias à cidade grega"; "Ela [a razão grega] desenvolveu-se menos através de técnicas que operam sobre o mundo do que por aquelas que visam conquistar outrem e nas quais a linguagem é o instrumento comum: a arte do político, do retórico, do professor. [...] Em seus limites como em suas inovações, ela é filha da cidade" Vernant, 1962, p. 143 e p. 145 respectivamente, tradução nossa.

22 “A fala não é mais a palavra ritual, a fórmula justa, mas o debate contraditório, a discussão, a argumentação. Ela supõe um público ao qual ela se dirige como a um juiz que decide, em última instância, de mãos levantadas, entre os dois partidos apresentados; é a escolha puramente humana que mede a respectiva força de persuasão dos dois discursos, que assegura a vitória de um dos oradores sobre seu adversário" Vernant, 1962, p. 57, tradução nossa.
}

RICKLI, Tiago. O teatro das relações n'As origens do pensamento grego de Vernant. Griot : Revista de Filosofia, Amargosa/Bahia, 


\section{Considerações finais}

Não há escrita em si, fala em si, grego em si, homem do damos em si, anax em si, registro contábil micênico em si, ou basileus em si, pois um modo de ser nada é fora da sua condição relacional, um agente apenas se diferencia juntamente àquilo que lhe é coexistente e não pré-existe em seu modo de ser ao exercício no qual ele se atualiza como tal. Incorporar ao debate oral um poder de decidir, isto é, modificar a fala num meio de decisão de questões políticas $e$ o grego num homem político, não corresponde a um gesto unilateral que produziria sobre um objeto um efeito externo e isolado, mas exprime uma mudança multilateral, de modo que o agente que nele se investe com sua capacidade de agir e reagir faz variar a relacionabilidade que se entretém. Não se dirá, portanto, que a fala é relativa ao homem ou que o homem é relativo à fala, mas que ambos são relativos à diferença que entretêm atualmente, deste ou daquele modo. Do ponto de vista relacional, não há a anterioridade de um termo em relação ao outro, mas a sua dupla contemporaneidade à relação entretida.

As diferenças entre os diferentes não colocam estes em exterioridade uns aos outros, mas numa continuidade assimétrica em que tanto as laterais escorrem com o rio como o rio escorre com as laterais, ou seja, em que tanto os diferentes se diferenciam reciprocamente com as relações que entretêm, quanto essas relações constituintes se firmam ou desmancham com aqueles que as atualizam. Ora, descrevendo seus objetos "lateralmente", isto é, não pela Forma que eles teriam em si e por si, mas pelas linhas que se estendem de sua condição de relacionabilidade, Vernant demonstra em seus estudos que uma história, seja ela a do palacianismo micênico ou da polis grega, não é escrita com Formas ou Essências, mas na interatividade em que os personagens, papéis e funções de uma complexa rede de relações reciprocamente se distribuem. Com efeito, como mostrado por Vernant, o hoplita não incorpora à sua capacidade de agir o exercício da função política, não se transfigura em soldado e cidadão, sem que os hippias correspondentemente se transformem em seu modo de existência, isto é: aprendam a batalhar em falange, ombro a ombro, lado a lado,

\footnotetext{
a manter a posição, a marchar em ordem, a se lançar em compasso contra o inimigo, a cuidar para não sair de seu lugar em meio à batalha.[...] uma completa mestria de si, um controle constante para se submeter a uma disciplina comum, o sangue frio necessário para refrear os impulsos instintivos que ameaçariam a ordem geral da formação (Vernant, 1962, p. 70-71, tradução nossa)
}

Mas se Vernant demonstra que uma ação é inseparável das relações em que ela se diferencia, que um modo de ser não pré-existe à rede de relações em que ele se atualiza, ele também nos mostra que o sentido de uma ação não precede à interação que o exprime. No teatro das relações de Vernant, as animações são autóctones e contemporâneas às ações ou os gestos que as assinalam, elas se diferenciam na mesma velocidade que o fluxo dos movimentos que as exprimem. Há uma expressividade do devir do hoplita em cidadão da polis, do devir da escrita pública e comum em Lei, da fala em meio de decisão política, tanto quanto há uma expressividade da situação do basileus micênico, daquela do basileus homérico, e das ações e reações que, em seu complexo conjunto, maquinam o palacianismo do anax. N'As Origens do Pensamento 
Greco de Vernant, a história é uma história de interações, e essas interações se exprimem nas relações em que elas se diferenciam.

RICKLI, Tiago. O teatro das relações n'As origens do pensamento grego de Vernant. Griot : Revista de Filosofia, Amargosa/Bahia, 


\section{Referências Bibliográficas}

DELEUZE, Gilles. Différence et Répétition. Paris : PUF, 1968.

LAÉRCIO, Diógenes. In: Os Pensadores: Os pré-socráticos. Tradução de Wilson Regis. São Paulo : Nova Cultural, 1989.

SILS Maria. Produzido por Charles Gillibert e dirigido por Olivier Assayas. [S.I] : CG Cinéma, Pallas Film, CAB Productions, Vortex Sutra, Arte France Cinéma, Orange Studio, Radio Télévision Suisse, SRG SSR idée suisse, 2014. 123 minutos.

VERNANT, Jean-Pierre. Les Origines de la Pensée Grecque. Paris : PUF, 1962.

Autor(a) para correspondência: Tiago Rickli, Universidade Federal do Paraná, Rua Dr. Faivre, 405, CEP 80060-140, Curitiba - PR, Brasil. tiago.rickli@gmail.com 